\title{
Productivity and Dry Matter Accumulation of Sugarcane Crop under Irrigation and Nitrogen Application at Rio Verde G0, Brazil
}

\author{
Alefe Viana Souza Bastos*, Renato Campos de Oliveira, Nelmício Furtado da Silva, \\ Marconi Batista Teixeira, Frederico Antonio Loureiro Soares, Edson Cabral da Silva \\ Instituto Federal Goiano (IFgoiano), Rio Verde, Brazil \\ Email: ${ }^{*}$ alefe viana@hotmail.com, renatocampos52@hotmail.com, nelmiciofurtado@gmail.com, \\ marconibt@gmail.com, fredalsoares@hotmail.com, edsoncabralsilva@gmail.com
}

Received 18 August 2015; accepted 20 September 2015; published 23 September 2015

Copyright @ 2015 by authors and Scientific Research Publishing Inc.

This work is licensed under the Creative Commons Attribution International License (CC BY). http://creativecommons.org/licenses/by/4.0/

(c) (7) Open Access

\begin{abstract}
Dry matter production and productivity of stem currently are being widely studied in sugarcane, reinforcing the study in question, which aims to assess the accumulation of dry matter of the aerial segment and the productivity of stems of sugarcane crops within the first cycle, at different levels of water replacement (WR) with and without nitrogen fertilization, through a subsurface drip irrigation system. The assay was conducted in the experimental area of the Federal Institut Goiano, Campus Rio Verde, GO, Brazil, in a dystroferric Rhodic Hapludox soil, cerrado phase (savannah), and comprised experimental splits of three furrows with an 8-meter long double row. Experimental design consisted of randomized blocks in a $5 \times 2$ factorial array, with four replications. Evaluated factors comprised five levels of WR $(100 \%, 75 \%, 50 \%, 25 \%$ and $0 \%$ of field capacity), with and without the application of nitrogen ( 0 and $\left.100 \mathrm{~kg} \cdot \mathrm{ha}^{-1} \mathrm{urea}\right)$. Harvest occurred in May 2013 and stem productivity (SP), productivity of pointers (PP), productivity of straw (PS), harvest index (HI), dry matter of stem (DMS), dry matter of pointers (DMP), the relationship between dry matter of pointer and dry matter of stem (DMP/DMS) and total dry matter of the aerial segment (TDM) were determined. The variables SP, PP, DMS and DMP had a linear growth in proportion to WR increase, whereas HI and DMP/DMS adjusted to a quadratic model. Nitrogen fertilization affected positively the variables SP, HI, DMS and DMP/DMS and occurred interaction to TDM; also increasing the productivity stem and the harvest index.
\end{abstract}

\section{Keywords}

Sugarcane Ratoon, Water Replacement, Nitrogen Fertilizer

\footnotetext{
${ }^{*}$ Corresponding author.
}

How to cite this paper: Bastos, A.V.S., de Oliveira, R.C., da Silva, N.F., Teixeira, M.B., Soares, F.A.L. and da Silva, E.C. (2015) Productivity and Dry Matter Accumulation of Sugarcane Crop under Irrigation and Nitrogen Application at Rio Verde GO, Brazil. American Journal of Plant Sciences, 6, 2374-2384. http://dx.doi.org/10.4236/ajps.2015.614240 


\section{Introduction}

Sugarcane is one of the most important crops in Brazil due to its great socio-economic relevance in the production of several products, mainly biofuel used worldwide. Brazil is currently the biggest world producer of sugarcane with a total production of crushed sugarcane for the 2014-15 harvest estimated at 642.1 millions of tons, cultivated in approximately 9004.5 thousands of hectares in the producing states [1].

According to Silva et al. [2], for maximum yield, sugarcane needs adequate moisture, directly proportional to the transpired water, throughout its vegetal growth. Thus, irrigation becomes indispensable for greater productivity.

Useful information may be found in the literature on responses and benefits of nitrogen in sugarcane plants. Several authors report that responses to the nutrient are generally more frequent in sugarcane ratoon than in the sugar plant and that the crop absorbs between $50 \%$ and $60 \%$ of the $\mathrm{N}$ amount applied to the soil [3]-[5]. However, for higher productivity, the interaction of the plant's genetic factors, climate, soil and management must be taken into account [6].

The dry matter of the aerial segment is also relevant. In mechanized sugarcane harvest, part of the phytomass, mainly comprising leaves and pointers (leaves at the tip of the stem), is placed on the soil as a soil cover or chaff. Chaff is not only a protection but provides nutrients and improves the soil's physical and chemical properties [7] [8] and, at the same time, may enhance the temporary immobilization of nitrogen [6]. The production of dry matter is one of the most studied variables in assays on agriculture. According to Faroni et al. [9], sugarcane phytomass comprises all vegetal matter ranging from the aerial segment to the radicular system (rhizomes and roots).

In the medium and long terms, soil may accumulate organic $\mathrm{C}$ and $\mathrm{N}$ when sugarcane is managed without burning, even though, in the short term, the amount of residues with high $\mathrm{C} / \mathrm{N}$ may demand more mineral $\mathrm{N}$ due to microbial immobilization. Several studies have shown that the best $\mathrm{N}$ dose should be $60 \mathrm{~kg} \cdot \mathrm{ha}^{-1}$, which is higher than that used in burnt sugarcane [10]. Current analysis may provide important information on nitrogen fertilization associated with irrigation and may contribute towards recommendations for nitrogen fertilizers and the rational use of water in sugarcane crops in the soil-climate conditions of the Brazilian savannah.

The method of harvesting sugarcane without the use of fire, mandatory by environmental legislation, implies in the management of nitrogen fertilization concerning doses, sources and methods of application. Non-burnt sugarcane produces residues of dry leaves and pointers on the soil which may vary between 10 and $^{20} \mathrm{t} \cdot \mathrm{ha}^{-1}$ dry matter, a C/N ratio above 100 and $\mathrm{N}$ contents between 40 and $80 \mathrm{~kg} \cdot \mathrm{ha}^{-1}$ [11] [12]. Consequently, when straw decomposes, some $\mathrm{N}$ rates may be absorbed by the subsequent stubbles and others may supply the $\mathrm{N}$ stock in the soil [12] [13].

Current analysis quantifies the dry matter of the aerial segment of the plant and evaluates the productivity of the sugarcane stem, pointers and straw in sugarcane ratoon at different levels of water replacement (WR) with and without nitrogen fertilization with surface drip irrigation system.

\section{Material and Methods}

\subsection{Experimental Conditions}

Current study was conducted in the experimental area of the Instituto Federal Goiano, campus Rio Verde GO Brazil, at $17^{\circ} 48^{\prime} 28^{\prime \prime S}$ and $50^{\circ} 53^{\prime} 57^{\prime \prime} \mathrm{W}$, mean altitude $720 \mathrm{~m}$. The region's climate may be classified as tropical Aw, following Köppen [14], with a rainy season between October and May and a dry season between May and September. Mean annual temperature varies between $20^{\circ} \mathrm{C}$ and $35^{\circ} \mathrm{C}$, with yearly rainfall between 1500 and $1800 \mathrm{~mm}$; land relief is moderately undulated (6\% declivity).

The study was carried in a soil classified as Dystropherric Typic Rhodic Hapludox soil [15], and Dystroferric Red Latosol (LVdf), medium texture, cerrado (savannah) phase. For characterization physical and chemical of soil (Table 1), a representative sub-sample was sieved to $2 \mathrm{~mm}$ and analyzed according to methodology described in EMBRAPA, [16].

Sugarcane, variety RB 85 - 5453 characterized by toughness and fastness, was planted in March 2011. This variety was chosen due to adaptability to the savannah and for having large acreage in the region. Experimental splits with three furrows and double rows (W-like planting) were established for current experiment. Spacing comprised $1.80 \mathrm{~m}$ between the double rows and $0.4 \mathrm{~m}$ between the 8-meter rows, totaling $35.2 \mathrm{~m}^{2}$ per split. Planted area comprised two linear meters of the central row of each split.

The first ratoon cycle started in May 2012, when it was found in third day after the cut the first buds; the treatments were maintained under the same conditions as those of the sugarcane crop; after 390 days from the 
Table 1. Physical, water and chemical characteristics of the soil in the experiment area, at layers $0-0.20$ and $0.20-0.40 \mathrm{~m}$ deep.

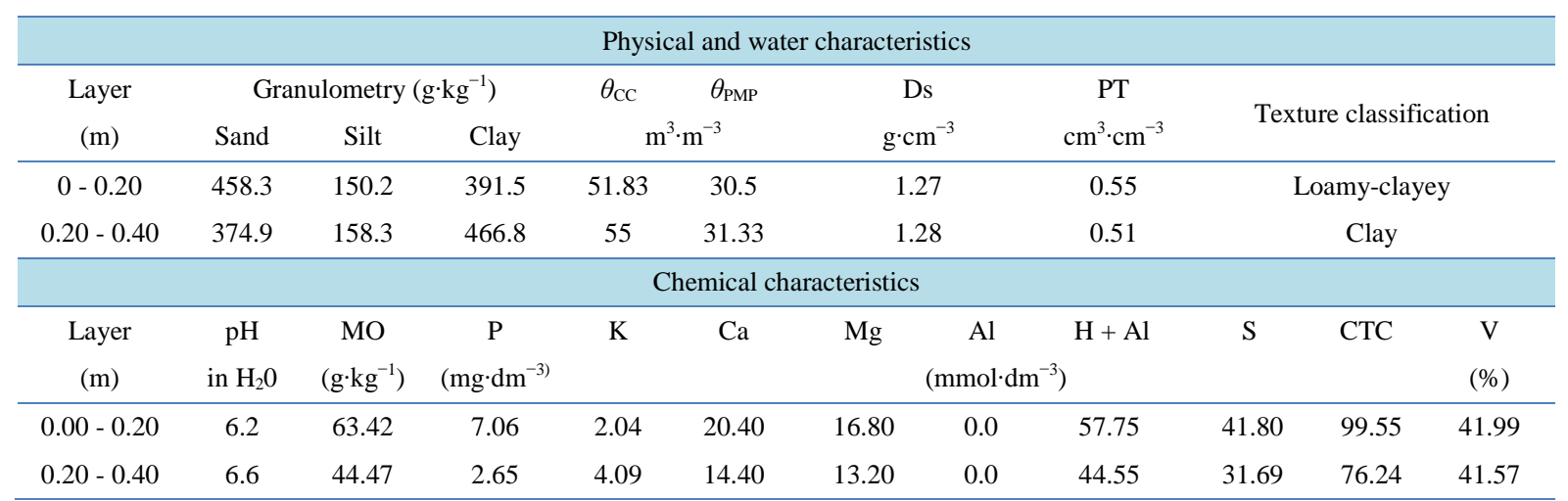

$\theta_{\mathrm{CC}}$, field capacity $(10 \mathrm{KPa}) ; \theta_{\mathrm{PMP}}$, permanent wilting site $(1.500 \mathrm{KPa})$; Ds, soil density; PT, total porosity; pH in distilled water. P and $\mathrm{K}$, extractor Mehlich $^{-1}$. M.O_organic Matter. V-Saturation per base.

first cutting, the first ratoon (on which current study focuses) was harvested (May 2013).

\subsection{Experimental Design}

The experimental design comprised $5 \times 2$ randomized blocks, with four replications; treatments consisted of a combination of 5 levels of water replacement (100\%, $75 \%, 50 \%, 25 \%$ and $0 \%$ of field capacity), with or with the application of $\mathrm{N}$-fertilizer ( 0 and $100 \mathrm{~kg} \cdot \mathrm{ha}^{-1}$; urea).

\subsection{Irrigation Management}

Irrigation system consisted of a drip tube $20 \mathrm{~cm}$ deep, between two furrows, featuring the following characteristics: drip tube (model Dripnet PC 16150), with thin walls; pressure at $1.0 \mathrm{bar}$; nominal discharge $1.0 \mathrm{~L} \cdot \mathrm{h}^{-1}$; spacing between drips equivalent to $0.50 \mathrm{~m}$.

Irrigation was conducted by $0.1 \mathrm{kPa}$ sensitive digital tension meter and tension probes were installed at depths $0.20,0.40,0.60$ and $0.80 \mathrm{~m}$, at $0.15,0.30,0.45$ and $0.60 \mathrm{~m}$ distance from the drip tube. Critical tension $40 \mathrm{kPa}$ and depth $0.40 \mathrm{~m}$ were employed to assess irrigation needs. The physical and hydric characteristics of the soil were determined by the water retention curve in the soil according equation van Genuchten [17], was developed to convert measured $\Psi_{\mathrm{m}}$ into water contents in the soil $(\theta)$, minimizing the sum of the squares of the deviations, with software RETEC, to obtain the parameters of adjustment used in Equation (1):

$$
\theta=\frac{0.5643}{\left[1+\left(0.2933\left|\Psi_{m}\right|\right)^{1.4937}\right]^{0.330522}}
$$

where

$\theta=$ contents of water in the soil $\left(\mathrm{g} \cdot \mathrm{g}^{-3}\right)$;

$\Psi_{\mathrm{m}}=$ matrix potential (mca).

Daily results of water content in the soil determined applied water volume for each level of water replacement. The $100 \%$ treatments were based on the rise of soil moisture for field capacity.

Treatments received $120 \mathrm{~kg} \cdot \mathrm{ha}^{-1} \mathrm{P}_{2} \mathrm{O}_{5}$ (source, simple superphosphate) and $80 \mathrm{~kg} \cdot \mathrm{ha}^{-1} \mathrm{~K}_{2} \mathrm{O}$ (source, potassium oxide), following the soil's chemical analysis and recommendations by Sousa \& Lobato [18]. The Phosphate fertilizers were applied in the furrows in its entirety in planting, whereas nitrogen and potassium (parceled out in four times) were placed on the coverage in treatment $0 \%$ of water replacement with irrigation water throughout the cane ratoon development cycle in water replacement treatments. Ten equal $\mathrm{N}$ applications, equivalent to $10 \mathrm{~kg}$, were applied throughout the crop cycle, with a total of $100 \mathrm{~kg} \cdot \mathrm{ha}^{-1}$.

At the end of the experiment, the water supply in the soil was measured to determine the volume of water supplied. Rates amounted to $0,115,230,345$ and $460 \mathrm{~mm}$ for water replacement of $0 \%, 25 \%, 50 \%, 75 \%$ and $100 \%$ of soil moisture. Effective rainfall $(1015.33 \mathrm{~mm})$ during the experiment was also calculated (Figure 1). A ten-day water balance for sugarcane management was estimated, based on climatological data during the expe- 
rimental period, according to method by Thornthwaite \& Mather [19]. Reference Evapotranspiration $\left(\mathrm{ET}_{0}\right)$ was calculated by Penman-Monteith equation [20].

\subsection{Variables Review}

The entire area of each split was harvested. Stems were weighed to determine productivity (SP, t $\left.\cdot \mathrm{ha}^{-1}\right)$; pointers and straw were weighed to determine productivity of pointers (PP, $t \cdot h a^{-1}$ ) and straw (PS, $t \cdot h a^{-1}$ ), respectively. Rates were obtained by the proportional relationship of the harvested area and calculated for one hectare. Weighing was done by a $100 \mathrm{~kg}$ clock-type scale, subdivided into $500 \mathrm{~g}$. Methodology derived from several studies on sugarcane crop [22] [23].

So that the dry matter of the stem (DMS, $t \cdot \mathrm{ha}^{-1}$ ) and the dry matter of the pointer (DMP, $\mathrm{t} \cdot \mathrm{ha}^{-1}$ ) could be calculated, the samples were harvested and dried in a forced air-circulation buffer at $65^{\circ} \mathrm{C}-70^{\circ} \mathrm{C}$ and then weighted in a precision balance with maximum capacity $3200 \mathrm{~g}$ and $0.01 \mathrm{~g}$ precision.

Total dry matter of the aerial segment (TDM, $\mathrm{tha}^{-1}$ ) was calculated by the sum of DMS and DMP, whilst the relationship between the dry matter of the pointer and stem (DMP/DMS) was calculated by dividing DMP by DMS, as described above.

Harvest Index (HI) measured the efficiency of the conversion of products synthetized in material of economic relevance, following Marafon [24], by Equation (2). In the case of mature culture, HI is defined as the ratio between dry matter mass of the economically profitable fraction (economic DM), or rather, the stems of the sugarcane crop, and TDM of the aerial segment.

$$
\mathrm{HI}=\frac{\mathrm{DM}_{\text {economic }}}{\mathrm{TDM}}
$$

where

$\mathrm{HI}=$ harvest Index;

$\mathrm{DM}_{\text {economic }}=$ economic Dry Matter $\left(\mathrm{t} \cdot \mathrm{ha}^{-1}\right)$;

$\mathrm{TDM}=$ total dry matter of the aerial segment $\left(\mathrm{t} \cdot \mathrm{ha}^{-1}\right)$.

\subsection{Statistical Analysis}

Data were submitted to analysis of variance by F-test at 0.05 probability; in significant cases, analysis of linear

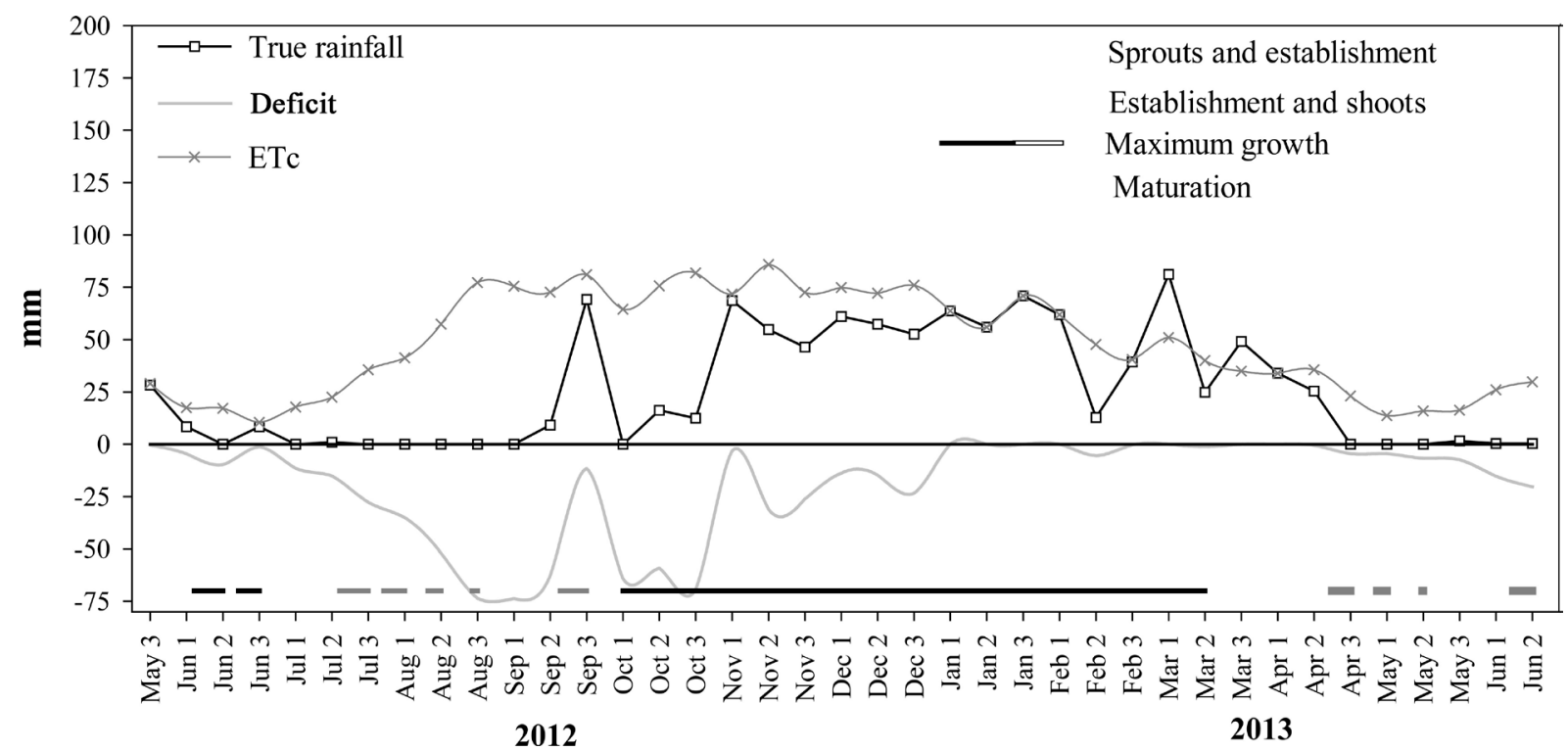

ETc-Evapotranspiration of crop. Crop phases (adapted from doorenbos and Kassam [21]): Sprouts and Establishment (Kc = 0.6); Establishment and shoots $(\mathrm{Kc}=0.9$ to 1.1$)$; Maximum growth $(\mathrm{Kc}=1.3)$; Maturation $(\mathrm{Kc}=0.7$ to 0.9$)$.

Figure 1. Ten-day water balance in Rio Verde during the experimental period (sugarcane ratoon). Source: FESURV Meteorological Station-Universidade de Rio Verde, Rio Verde GO., Brazil. 
and quadratic polynomial regression was undertaken to calculate water replacement levels of; in the case of $\mathrm{N}$ application, means were compared by Tukey's test at 0.05 probability. Statistical software SISVAR-ESAL was employed [25].

\section{Results and Discussion}

Table 2 shows that water replacement affected significantly all the variables under analysis, with the exception of PS. In N applications, there were significant differences for stem productivity (SP) and harvest index (HI), but no significant interaction between the factors studied for the assessed variables. There was an increase of $17.85 \mathrm{t} \cdot \mathrm{ha}^{-1}$ for SP as a response for the application of $\mathrm{N}$-fertilizer when compared to N-less treatments, where a $2.5 \%$ increase occurred for HI. As reported in current study and in several research works, sugarcane ratoon responds favorably to nitrogen application. Souza [26], reports that treatment without nitrogen fertilization had an increase of 5.04 and $7.41 \mathrm{t} \cdot \mathrm{ha}^{-1}$, when compared to 120 and $240 \mathrm{~kg} \cdot \mathrm{ha}^{-1} \mathrm{~N}$ doses, or rather, lower than the increase reported in current study. The result can be attributed to differences between cultivars, or even by soil type and/or nitrogen source applied.

Rípoli et al. [27] reported that sugarcane produces between 9\% and 14\% of straw (dry matter base), with approximately $10 \mathrm{t} \cdot \mathrm{ha}^{-1}$. Although not affected by evaluated factors, straw production in current analysis ranged between 15.92 and $17.16 \mathrm{t}^{-h^{-1}}{ }^{-1}$, higher than rates by the former authors.

The variables stem productivity and pointer productivity had a linear behavior for WR (Figure 2). There was a $22.6 \mathrm{t}^{\mathrm{h}} \mathrm{ha}^{-1}$ increase in stem production for a $25 \%$ increase of WR, with the highest productivity at $233.4 \mathrm{t} \cdot \mathrm{ha}^{-1}$ stems for $100 \%$ WR (Figure 2(a)). The above WR is equivalent to a water depth of $1475.33 \mathrm{~mm}$ (100\% WR plus true rainfall). The above rates were higher than those by Haddad et al. [28] who studied stem productivity and sugar yields of sugarcane according to water depth. They also registered productivity rise in proportion to increase in water depth, with maximum rate at $125.9 \mathrm{t} \cdot \mathrm{ha}^{-1}$ for the application of $1854.4 \mathrm{~mm}$. Difference in productivity may have been caused by better water distribution throughout the sugarcane cycle coupled to different fertilizations, management, climate and varieties. However, results were similar to those given by Andrade Júnior et al. [29] and Barbosa et al. [30] with subsurface drip irrigation.

There was a $2.1 \mathrm{t}^{\mathrm{h}} \mathrm{ha}^{-1}$ increase of pointer productivity for every $25 \%$ WR increase, with highest productivity at $48.8 \mathrm{t}^{\mathrm{ha}} \mathrm{h}^{-1}$ at $100 \%$ water depth (Figure 2(b)). Increase in the productivity of pointers enhanced stem productivity, which may be due to the source-drain ratio, where the pointer is the energy source for the stems (drain), and to the unit increase (UI) of WR. In fact, UI was three times greater for stem productivity than UI for point productivity, and thus the greater development of the pointer caused a greater production of energy used by the sugarcane stems.

Table 2. Summary of the analysis of variance for stem productivity (SP), straw productivity (PS), productivity of pointer (PP) and harvest index (HI) of sugarcane at different levels of water replacement (WR), with or without $\mathrm{N}$ application.

\begin{tabular}{|c|c|c|c|c|c|}
\hline \multirow{2}{*}{ Variation source } & \multirow{2}{*}{$\mathrm{DF}$} & \multicolumn{4}{|c|}{ Mean square } \\
\hline & & SP & PS & PP & HI \\
\hline Water replacement (WR) & 4 & $10541.56^{* *}$ & $4.44^{\mathrm{ns}}$ & $104.34^{* *}$ & $26.73^{* *}$ \\
\hline Nitrogen $(\mathrm{N})$ & 1 & $3186.40^{* *}$ & $15.44^{\mathrm{ns}}$ & $1.38^{\mathrm{ns}}$ & $39.76^{*}$ \\
\hline Interaction $\mathrm{WR} \times \mathrm{N}$ & 4 & $96.98^{\text {ns }}$ & $12.71^{\mathrm{ns}}$ & $30.73^{\text {ns }}$ & $1.55^{\mathrm{ns}}$ \\
\hline Blocks & 3 & $43.43^{\text {ns }}$ & $25.75^{\text {ns }}$ & $27.12^{\text {ns }}$ & $4.95^{\mathrm{ns}}$ \\
\hline Residue & 27 & 182.68 & 14.16 & 12.02 & 6.68 \\
\hline CV (\%) & & 7.18 & 22.76 & 7.77 & 3.20 \\
\hline Nitrogen $(\mathrm{N})$ & & \multicolumn{2}{|c|}{ Means $\left(t \cdot h^{-1}\right)$} & \multicolumn{2}{|c|}{ Mean (\%) } \\
\hline With & & $197.06 \mathrm{a}$ & $17.16 \mathrm{a}$ & 44.46 a & $81.90 \mathrm{a}$ \\
\hline without & & $179.21 \mathrm{~b}$ & $15.92 \mathrm{a}$ & 44.83 a & $79.90 \mathrm{~b}$ \\
\hline LSD & & 8.76 & 2.44 & 2.23 & 1.68 \\
\hline SE & & 3.02 & 0.84 & 0.77 & 0.58 \\
\hline
\end{tabular}

${ }^{* * *}$ Significant at 0.01 probability by F-test; ${ }^{*}$ Significant at 0.05 probability by F-test; ${ }^{\text {ns }}$ not significant at 0.05 probability by F-test; Means followed by the same letter in the columns do not differ statistically at 0.05 probability by Tukey's test; LSD (least significant difference); SE (standard errors); DF (Degrees of freedom); SP (stem productivity); PS (straw productivity); PP (productivity of pointer); HI (harvest index). 
Results for the different levels of water replacements show that the harvest index (HI) had a quadratic behavior (Figure 3(a)). HI results increased up to $70.22 \%$ at an estimated rate of 82.63 ; they decreased in proportion to water replacement increase. According to Doorenbos and Kassam [31], 80\% may be adopted for sugarcane crops since it is close to obtained results. In fact, rates varied between 77.94 and 82.63, following water replacements.

Table 3 shows that variables DMS, DMP and DMP/DMS were significantly affected by WR. Application of $\mathrm{N}$ caused a significant effect on variables DMS and DMP/DMS, with an increase of $8.16 \mathrm{t} \cdot \mathrm{ha}^{-1}$ and $13.64 \%$ for the respective variables, when compared to non-application of N. Total dry matter (TDM) of the aerial segment was the only variable which significantly differed with regard to $\mathrm{WR} \times \mathrm{N}$.

Cantarella [32] assessed sugarcane response to $\mathrm{N}$ application in a three-year period and verified that the production of the dry matter of the stem was significantly higher in urea-fertilized crops $\left(100 \mathrm{~kg} \cdot \mathrm{ha}^{-1} \mathrm{~N}\right)$. Moreover, the residual effect of fertilization was also confirmed in the following year. Results demonstrate that the application of $\mathrm{N}$ in sugarcane crops increases the dry matter of the stem and final productivity.

Variables DMP and DMS exhibited a linear behavior for WR (Figure 4). The amount of dry matter accumulated in the pointer (DMP) due to water replacement varied between 10.96 and $14.77 \mathrm{t} \cdot \mathrm{ha}^{-1}$. There was a $0.35 \%$ increase in DMP for every $1 \%$ increase in WP, or rather, a gain of $0.038 \mathrm{t} \cdot \mathrm{ha}^{-1}$ (Figure 4(a)). Therefore, the accumulation of dry matter in the pointer increases in proportion to water increase. Oliveira et al. [33] reported rates between 7.5 and $12.0 \mathrm{t} \cdot \mathrm{ha}^{-1}$ for DMP in irrigated sugarcane varieties, similar to that in current analysis.

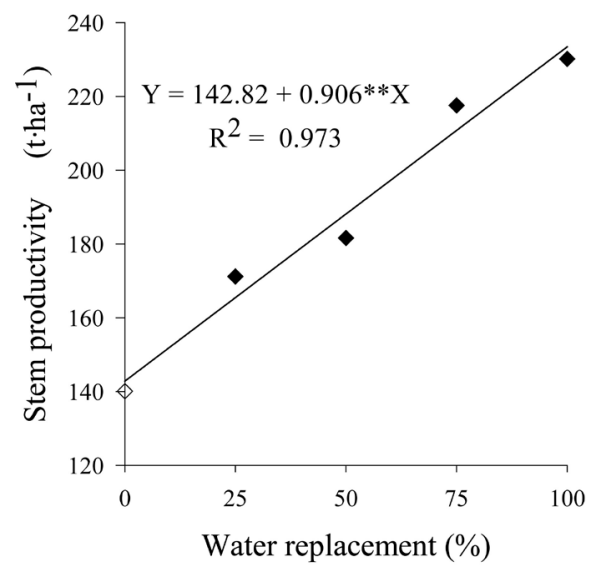

(a)

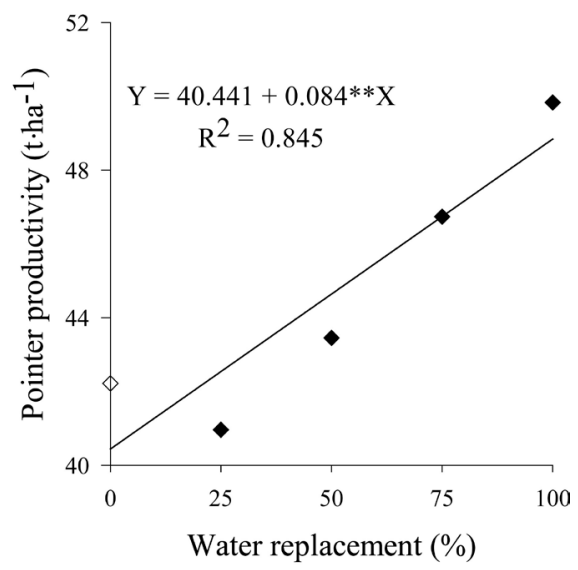

(b)

${ }^{* *}$ and ${ }^{*}$ respectively significant at $\mathrm{p}<0.01$ and 0.05 , according to F-test.

Figure 2. Productivity of sugarcane stems (a) and pointers (b), due to water replacement.

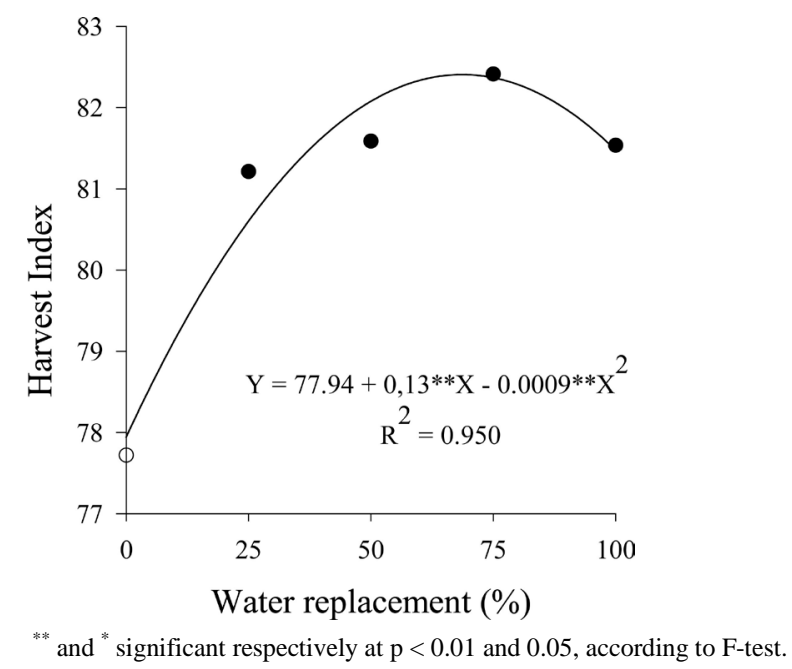

Figure 3. Harvest Index of sugarcane according to water replacement. 
Table 3. Summary of the analysis of variance for dry matter of stem (DMS), dry matter of pointer (DMP), DMP/DMS ratio and total dry matter from the aerial segment (TDM), at different levels of water replacement, with and without the application of Nitrogen.

\begin{tabular}{|c|c|c|c|c|c|}
\hline \multirow{2}{*}{ Variation source } & \multirow{2}{*}{$\mathrm{DF}$} & \multicolumn{4}{|c|}{ Mean square } \\
\hline & & DMS & DMP & DMP/DMS & TDM \\
\hline Water replacement (WR) & 4 & $1004.48^{* *}$ & $21.67^{* *}$ & $0.0068^{* *}$ & $1292.47^{\text {ns }}$ \\
\hline Nitrogen (N) & 1 & $666.26^{* *}$ & $0.26^{\mathrm{ns}}$ & $0.0096^{*}$ & $693.06^{\mathrm{ns}}$ \\
\hline $\mathrm{WR} \times \mathrm{N}$ interaction & 4 & $71.61^{\mathrm{ns}}$ & $1.28^{\mathrm{ns}}$ & $0.0004^{\mathrm{ns}}$ & $86.22^{*}$ \\
\hline Blocks & 3 & $20.52^{\text {ns }}$ & $6.37^{\mathrm{ns}}$ & $0.0012^{\mathrm{ns}}$ & $45.75^{\mathrm{ns}}$ \\
\hline Residues & 27 & 32.77 & 2.18 & 0.0017 & 32.08 \\
\hline CV (\%) & & 10.29 & 11.49 & 17.51 & 8.27 \\
\hline Nitrogen $(\mathrm{N})$ & & \multicolumn{2}{|c|}{ Means $\left(\mathrm{t} \cdot \mathrm{ha}^{-1}\right)$} & Means & Means $\left(\mathrm{t} \cdot \mathrm{ha}^{-1}\right)$ \\
\hline With & & 59.73 a & $12.94 \mathrm{a}$ & $0.25 \mathrm{a}$ & 72.67 a \\
\hline Without & & $51.57 \mathrm{~b}$ & $12.78 \mathrm{a}$ & $0.22 \mathrm{~b}$ & $64.35 \mathrm{~b}$ \\
\hline LSD & & 3.71 & 0.96 & 0.03 & 3.67 \\
\hline SE & & 1.28 & 0.33 & 0.009 & 1.27 \\
\hline
\end{tabular}

${ }^{* *}$ Significant at 0.01 probability by F-test; * Significant at 0.05 probability by F-test; ${ }^{\text {ns }}$ not significant at 0.05 probability by F-test; Means followed by the same letter in the columns do not differ statistically at 0.05 probability by Tukey's test; LSD (least significant difference); SE (standard errors); DF (degrees of freedom); DMS (dry matter of stem); DMP (dry matter of pointer); TDM (total dry matter from the aerial segment).

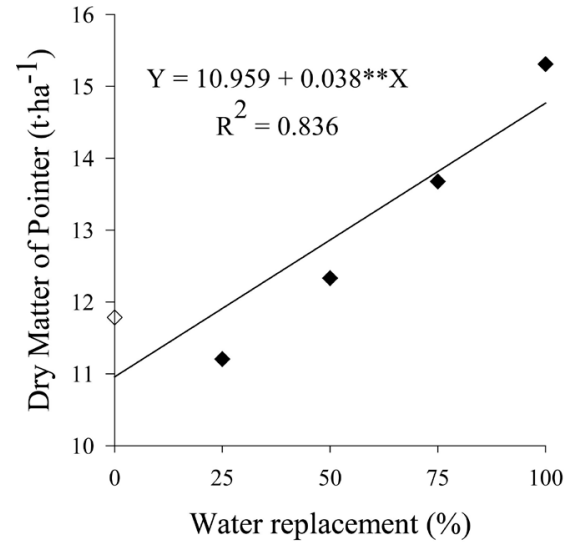

(a)

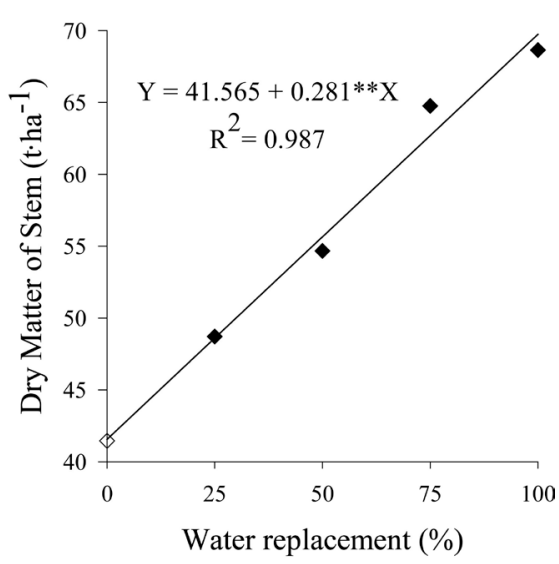

(b)

** and ${ }^{*}$ respectively significant at $\mathrm{p}<0.01$ and 0.05 , according to F-test.

Figure 4. Dry matter of sugarcane pointer (a) and dry matter of stem (b) according to water replacement.

Every $1 \%$ increase in WR, the increment for DMS is of $0.28 \mathrm{t} \cdot \mathrm{ha}^{-1}$ (Figure 4(b)), corroborating results by Farias et al. [34] who reported that water supply through irrigation provided an increase in the accumulation rate of the sugarcane stem's dry matter. Irrigated water supply for crops increases the production of dry matter of stem and pointer, underscoring that DMS production is 1.94 times greater than DMP production when there is a $1 \%$ WR increase by irrigation.

Therefore, irrigation increases the production of dry matter in the stem and, therefore, in sugarcane productivity. The above justifies the practice, especially when one observes in Figure 1 that true rainfall supplied the requirements of the crop (ETc) only during approximately 70 days within the entire cycle.

DMP/DMS ratio (Figure 5) had a quadratic behavior: all rates decreased till 66.6\%; from this point, rates increased due to WR. Relationship between pointer and stem revealed that the decrease of this index caused a proportional increase in the production of stems and a decrease in the production of pointers. Machado et al. [35] reported that after 100 days the dry matter of leaves and of pointer provided $70 \%$ of the plant's biomass and that, after this period, there was a progressive decrease in the accumulation of dry matter, or rather, $9 \%$ of dry matter accumulated by the plant at the end of the cycle. 
Figure 6 shows total dry matter from the aerial segment behavior in sugarcane ratoon: when nitrogen was applied, productivities were estimated at 53.13; 62.88; 72.63; 82.38; $92.13 \mathrm{t}^{\mathrm{h} \mathrm{ha}^{-1}}$ respectively for water replacement $0 \%, 25 \%, 50 \%, 75 \%$ and $100 \%$; without the application of nitrogen, productivities were 51.91 ; 58.11 ; 64.31; 70.51; $76.71 \mathrm{t} \cdot \mathrm{ha}^{-1}$, respectively for the same WR percentages. All rates were higher in treatments with nitrogen, or rather, increase in water irrigation depth provided a proportionate increase in the difference between rates. In other words, the amount of available water for the plant affected the absorption of nitrogen.

Figure 6(a) demonstrates that the evolution of the WR $\times \mathrm{N}$ interaction increased linearly the productivity of total dry matter of the aerial segment. With regard to the evolution of WR for each $\mathrm{N}$ level, a 0.39 and 0.25 $t \cdot h a^{-1}$ increase occurred in the production of TDM in treatments with and without $\mathrm{N}$ for every $1 \%$ increase in WR. Consequently, irrigated sugarcane crops were more efficient in increasing TDM production when N-fertilizer was applied.

Above results disagree with those given by Arantes [36] who evaluated the production capacity of sugarcane cultivars with and without irrigation and reported but the cause of different results can be well attributed the cultivars used in the study of Arantes, since none were the same used in the current study. That there occurred no significant effect on the accumulation of total dry matter in each evaluation period.

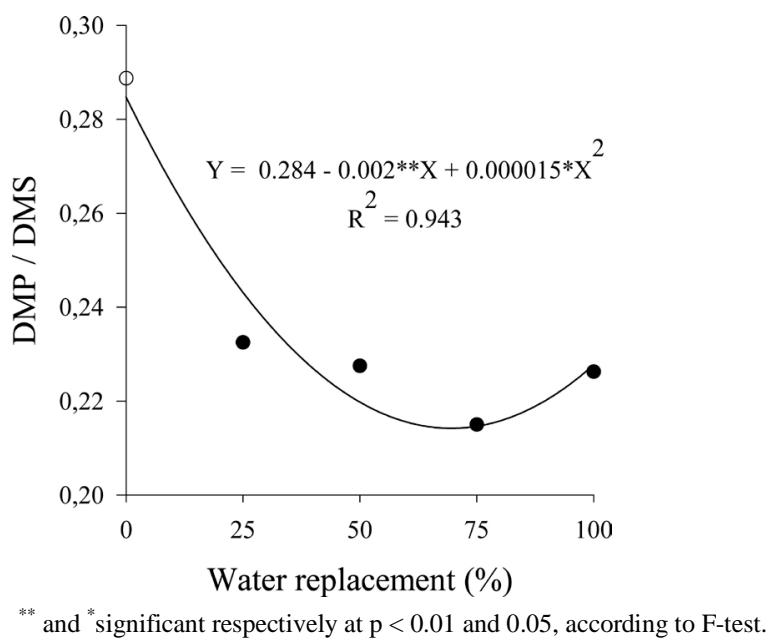

Figure 5. Harvest index of sugarcane according to water replacement.

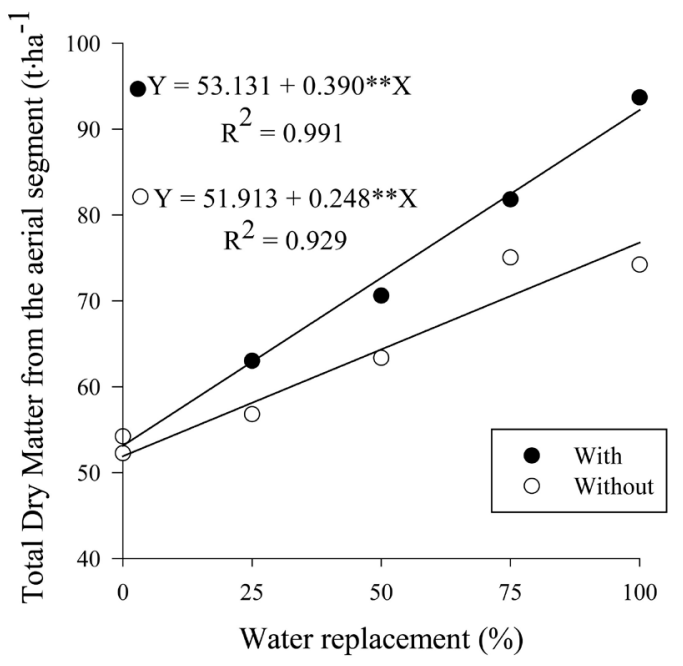

(a)

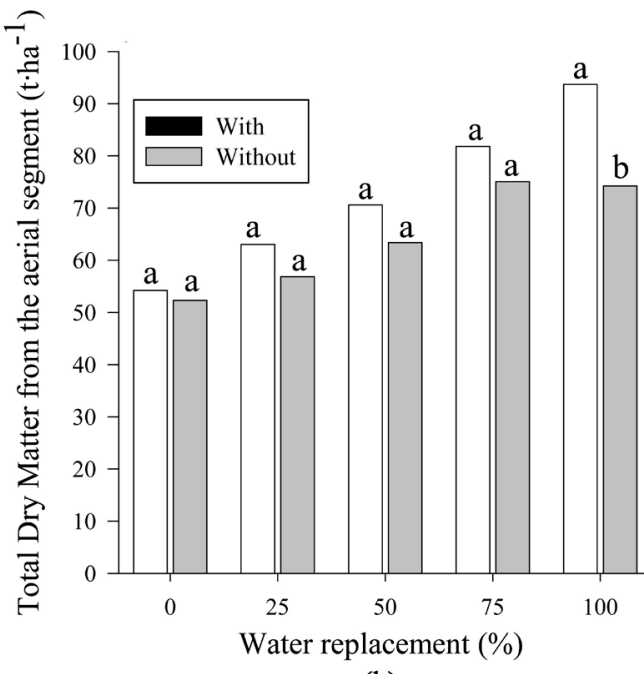

(b)

${ }^{*}$ and ${ }^{*}$ respectively significant at $\mathrm{p}<0.01$ and 0.05 , according to F-test.

Figure 6. Total dry matter of the sugarcane aerial segment due to water replacement for each application of nitrogen (a) and nitrogen application for each water replacement (b). 
There was only a significant difference for TDM in WR $100 \%$ with a $20.1 \%$ increase, according to the supply of the nutrient (Figure 6(b)). As a rule, there was a 12.93\% gain in the application of $\mathrm{N}$ at WR levels (Table 3 ).

Otto et al. [37] assessed the phytomass of roots and the aerial segment of sugarcane related to $\mathrm{N}$ fertilization and reported that splits which did not receive $\mathrm{N}$ fertilization showed great energy expenditure in the growth of the roots. This fact established a competition for photoassimilates in the growth of the aerial segment and also explained the low TDM rates in treatments without N-fertilizers in current assay.

\section{Conclusions}

Increase in water replacements significantly raised the productivity of dry matter in stems and pointers by the sugarcane.

There was an increase in harvest index up to water replacement 70.22\%; for the DMP/DMS ratio, harvest index decreased up to water replacement $66.6 \%$.

There was an increase of $90.61 \mathrm{t} \cdot \mathrm{ha}^{-1}$ in the productivity of stems and $8.40 \mathrm{t} \cdot \mathrm{ha}^{-1}$ in the productivity of pointers between treatments water replacement $0 \%$ and water replacement $100 \%$.

Nitrogen fertilization significantly increased the productivity of stems, harvest index, dry matter of stem and DMS/DMP ratio.

Nitrogen fertilization increased productivity by $8.16 \mathrm{t} \cdot \mathrm{ha}^{-1}$ for dry matter and $20.85 \mathrm{t} \cdot \mathrm{ha}^{-1}$ for stems; in the case of DMP/DMS, increase reached $13.64 \%$ and $2.5 \%$ for harvest index.

Total dry matter of the aerial segment was affected by $\mathrm{RH} \times \mathrm{N}$ interaction: highest rates occurred in water replacement $100 \%$ with the application of nitrogen. Straw productivity was not affected by any of the factors evaluated.

\section{Acknowledgements}

The authors would like to thank the Brazilian National Council for Scientific and Technological development (CNPq) for funding current assay. Thanks are also due to the Brazilian Coordination for the Updating of Higher Education Personnel (CAPES), to the Foundation for Research in the State of Goiás (FAPEG), to Financing Agent for Studies and Projects (FINEP) and to the Federal Institute of Goiás, Campus Rio Verde GO Brazil.

\section{References}

[1] (2015) CONAB - Companhia Nacional do Abastecimento. Acomp. da Safra Bras. de Cana-de-açúcar, V. 1-Safra 2014/15, N. 3-Terceiro Levantamento, Brasília, dez. 2014. 28 p. http://Www.Conab.Gov.Br

[2] Silva, C.T.S., Azevedo, H.M., Azevedo, C.A.V., Neto, J.D., Carvalho, C.M. and Filho, R.R.G. (2009) Crescimento da Cana-de-açúcar Com E Sem Irrigação Complementar Sob Diferentes Níveis de Adubação de Cobertura Nitrogenada e Potássica. Revista Brasileira de Agricultura Irrigada, 3, 3-12. http://dx.doi.org/10.7127/rbai.v3n100012

[3] Albuquerque, G.A.C. and Marinho, M.L. (1983) Adubação na Região Norte-Nordeste. In: Orlando Filho, J., Coord., Nutrição de Adubação da Cana-de-açúcar no Brasil. Instituto do Açúcar E do Álcool, Piracicaba, 267-286.

[4] Maeda, A.S., Buzetti, S. and Bolonhezi, A.C. (2009) Adubação Nitrogenada e Potássica na Qualidade e Produtividade da Cana-Soca. Stab, 27, 40-45.

[5] Teodoro, I.T., Neto, J.D., Souza, J.L., Lira, G.B., Brito, K.S., Sá, L.A., Santos, M.A.L. and Sarmento, P.L.V.S. (2013) Isoquantas de Produtividade da Cana-de-açúcar em Função de Níveis de Irrigação e Adubação Nitrogenada. Irriga, 18, 387-401. http://dx.doi.org/10.15809/irriga.2013v18n3p387

[6] Cantarella, H., Trivelin, P.C.O. and Vitti, A.C. (2007) Nitrogênio e Enxofre na Cultura da Cana-de-açúcar. In: Yamada, T., Abdalla, S.R.S. and Vitti, G.C., Eds., Nitrogênio e Enxofre na Agricultura Brasileira, Ipni Brasil, Piracicaba, 355412.

[7] Christoffoleti, P.J., Carvalho, S.J.P. de, López-Ovejero, R.F., Nicolai, M., Hidalgo, E. and Silva, J.E. (2007) Conservation of Natural Resources in Brazilian Agriculture: Implications on Weed Biology and Management. Crop Protection, 26, 383-389. http://dx.doi.org/10.1016/j.cropro.2005.06.013

[8] Aquino, G.S. de and Medina, C. de C. (2014) Produtividade e Índices Biométricos e Fisiológicos de Cana-de-Açúcar Cultivada Sob Diferentes Quantidades de Palhada. Pesquisa Agropecuária Brasileira, 49, 173-180. http://dx.doi.org/10.1590/S0100-204X2014000300003

[9] Faroni, C.E., Trivelin, P.C.O., Silva, P.H., Bologna, I.R., Vitti, A.C. and Franco, H.C.J. (2007) Marcação de Fitomassa de Cana-de-açúcar Com Aplicação de Solução de Uréia Marcada Com 15n. Pesquisa Agropecuária Brasileira, 42, 
851-857. http://dx.doi.org/10.1590/S0100-204X2007000600012

[10] Thorburn, P.J., dart, I.K., Biggs, I.J., Baillie, C.P., Smith, M.A. and Keating, B.A. (2002) The Fate of Nitrogen Applied to Sugarcane by Trickle Irrigation. Irrigation Science, In Press.

[11] Trivelin, P.C.O., Victoria, R.L. and Rodriguês, J.C.S. (1995) Aproveitamento Por Soqueira de Cana-de-açúcar de Final de Safra do Nitrogênio da Aquamônia ${ }^{15} \mathrm{n}$ E Ureia ${ }^{15} \mathrm{n}$ Aplicado ao Solo em Complemento à Vinhaça. Pesquisa Agropecuária Brasileira, 30, 1375-1385.

[12] Vitti, A.C., Franco, H.C.J., Trivelin, P.C.O., Ferreira, D.A., Otto, R., Fortes, C. and Faroni, C.E. (2011) Nitrogênio Proveniente da Adubação Nitrogenada e de Resíduos Culturais na Nutrição da Cana-Planta. Pesquisa Agropecuária Brasileira, 46, 287-293. http://dx.doi.org/10.1590/S0100-204X2011000300009

[13] Basanta, M.V., dourado Neto, D., Reichardt, K., Bacchi, O.O.S., Oliviera, J.C.M., Trivelin, P.C.O., Timm, L.C., Tominaga, T.T., Correchel, V., Cássaro, F., Pires, L.F. and Macedo, J.R. (2003) Management Effects on Nitrogen Recovery In a Sugarcane Crop Grown in Brazil. Geoderma, 116, 235-248. http://dx.doi.org/10.1016/S0016-7061(03)00103-4

[14] Castro Neto, P. (1982) Notas de Aula Prática do Curso de Agrometeorologia. Lavras, Esal, 45 p.

[15] Soil Survey Staff (2006) Keys to Soil Taxonomy. Tenth Edition, United States Department of Agriculture, Natural Resources Conservation Services.

[16] Embrapa Solos (2013) Empresa Brasileira de Pesquisa Agropecuária. Centro Nacional de Pesquisa de Solos. Sistema Brasileiro de Classificação de Solos. Rio de Janeiro.

[17] Van Genuchten M.T., Leij, F.J. and Yates, S.R. (2009) RETC, Code for Quantifying the Hydraulic Functions of Unsaturated Soils: Version 6.02. University of California, Riverside.

[18] Sousa, D.M.G. and Lobato, E. (2004) Cerrado: Correção do Solo E Adubação. 2nd Edition, Embrapa Informação Tecnológica, Brasília, 416 p.

[19] Thornthwaite, C.W. and Mather, J.R. (1955) The Water Balance, Laboratory of Climatology. Centerton, 8, 1-14.

[20] Monteith, J.L. (1973) Principles of Environmental Physics. Edward Arnold, London, 241 p.

[21] Doorenbos, J. and Kassam, A.H. (1994) Efeito da Água no Rendimento das Culturas. Ufpb, Campina Grande, 306 p. (Irrigação e Drenagem, Estudos Fao, 33).

[22] Silva, T.G.F., de Moura, M.S., Zolnier, S., Soares, J.M., Vieira, V.J.deS. and Júnior, W.F.G. (2011) Demanda Hídrica E Eficiência do Uso da Água da Cana-de-açúcar Irrigada no Semi-Árido Brasileiro. Revista Brasileira de Engenharia Agrícola e Ambiental, 15, 1257-1265. http://dx.doi.org/10.1590/S1415-43662011001200007

[23] Barros, A.C., Coelho, R.D., Marin, F.R., Polzer, D.L. and Netto, A.deO.A. (2012) Utilização do Modelo Canegro Para Estimativa de Crescimento da Cana-de-açúcar Irrigada E Não Irrigada Para As Regiões de Gurupi—To e Teresina—Pi. Irriga, 17, 189-207. http://dx.doi.org/10.15809/irriga.2012v17n2p189

[24] Marafon, A.C. (2012) Análise Quantitativa de Crescimento em Cana-de-açúcar: Uma Introdução ao Procedimento Prático. Se. $1^{\text {a }}$ Ed., Embrapa Tabuleiros Costeiros, Aracaju.

[25] Ferreira, D.F. (2011) Sisvar: A Computerstatisticalanalysis System. Ciência E Agrotecnologia, 35, 1039-1042.

[26] de Souza, J.P.S.P. (2012) Resposta da Cana-de-açúcar a Adubação Nitrogenada com Ureia Convencional e Revestida em Solo de Cerrado na Fazenda Água Limpa. Faculdade de Agronomia e Medicina Veterinária,Universidade de Brasília, Monografia (Agronomia), 34 p.

[27] Rípoli, T.C.C. and Rípoli, M.L.C. (2004) Biomassa de Cana-de-açúcar: Colheita, Energia e Ambiente. Usp/Esalq, Piracicaba, 302 p.

[28] Haddad, G.S.V., Mantovani, E.C., Sediyama, G.C., da Costa, E.L. and delazari, F.T. (2012) Produtividade de Colmos E Rendimento de Açúcares da Cana-de-açúcar em Função de Lâminas de Água. Irriga, 17, 234-244. http://dx.doi.org/10.15809/irriga.2012v17n2p234

[29] de Andrade Jr., A.S., Bastos, E.A., Ribeiro, V.Q., Duarte, J.A.L., Braga, D.L. and Noleto, D.H. (2012) Níveis de Água, Nitrogênio e Potássio por Gotejamento Subsuperficial em Cana-de-açúcar. Pesquisa Agropecuária Brasileira, 47, 7684. http://dx.doi.org/10.1590/S0100-204X2012000100011

[30] Barbosa, E.A.A., Arruda, F.B., Pires, R.C.M., da Silva, T.J.A. and Sakai, E. (2012) Cana-de-açúcar Fertirrigada com Vinhaça e Adubos Minerais Via Irrigação Por Gotejamento Subsuperficial: Ciclo Dda Cana-Planta. Revista Brasileira de Engenharia Agrícola e Ambiental, 16, 952-958. http://dx.doi.org/10.1590/S1415-43662012000900005

[31] Doorenbos, J. and Kassam, A.H. (1979) Yield Response to Water. FAO Irrigation and Drainage Paper, No. 33. FAO, Rome, $172 \mathrm{p}$.

[32] Cantarella, H. (2012) Avaliação de Resposta a N em Cana-de-açúcar Não Adubada Por Três Anos. (Relatório), Instituto Agronômico Centro ee Solos e Recursos Ambientais, Agrisus, Pesquisa Agronômica, 719/10.

[33] de Oliveira, E.C.A., de Oliveira, R.I., de Andrade, B.M.T., Freire, F.J., Júnior, M.A.L. and Machado, P.R. (2010) 
Crescimento e Acúmulo de Matéria Seca em Variedades de Cana-de-açúcar Cultivadas Sob Irrigação Plena. Revista Brasileira de Engenharia Agrícola e Ambiental, 14, 951-960. http://dx.doi.org/10.1590/S1415-43662010000900007

[34] de Farias, C.H.A., Fernandes, P.D., de Azevedo, H.M. and Dantas Neto, J. (2008) Índices de Crescimento da Cana-deaçúcar Irrigada e de Sequeiro no Estado a Paraíba. Revista Brasileira de Engenharia Agrícola e Ambiental, 12, 356362. http://dx.doi.org/10.1590/S1415-43662008000400004

[35] Machado, E.C., Pereira, A.R., Fahl, J.I., Arruda, J.V. and Cione, J. (1982) Índices Biométricos de Duas Cultivares de Cana-de-açúcar. Pesquisa Agropecuária Brasileira, 17, 1323-1329.

[36] Arantes, M.T. (2012) Potencial Produtivo de Cultivares de Cana-de-açúcar Sob os Manejos Irrigado e Sequeiro. Dissertação (Mestrado em Agronomia), Universidade Estadual Paulista Faculdade de Ciências Agronômicas, Botucatu, $65 \mathrm{p}$.

[37] Otto, R., Franco, H.C.J., Faroni, C.E., Vitti, A.C. and Trivelin, P.C.O. (2009) Fitomassa de Raízes e da Parte Aérea da Cana-de-açúcar Relacionada à Adubação Nitrogenada de Plantio. Pesquisa Agropecuária Brasileira, 44, 398-405. http://dx.doi.org/10.1590/S0100-204X2009000400010 